\title{
PERKEMBANGAN KARAKTER SISWA MELALUI \\ KEGIATAN EKSTRAKULIKULER PADUAN SUARA DI SD SANTO ANTONIUS I DAN II MEDAN
}

Oleh :

Lorencia Adella P.P.S

Program S1 Pendidikan Musik Jurusan Sendratasik Fakultas Bahasa dan Seni

Universitas Negeri Medan

\begin{abstract}
ABSTRAK
Hasil penelitian ini membuktikan bahwa kegaitan ekstrakulikuler paduan suara merupakan ekstrakulikuler pilihan, yang diresmikan sejak Oktober 2010. Kegiatan ini memiliki produk bernama paduan suara Beata Voce. Terdapat tujuh karakter yang ditemukan dalam kegiatan ekstrakulikuler paduan suara. Antara lain Tanggung jawab, Disiplin, Kerja keras, Teguh pendirian, Religius, Komitmen, dan bersahabat/ komunikatif. Berdasarkan indikator perkembangan karakter, siswa dalam kelompok suara Sopran 1 berada dalam kondisi sangat baik, siswa dalam kelompok suara Sopran 2 berada dalam kondisi sangat baik, siswa dalam kelompok suara Alto 1 berada dalam kondisi baik, dan siswa dalam kelompok suara Alto 2 berada dalam kondisi baik, dan karakter yang kurang maksimal pengembangannya dalah kerja keras. Kendala dari perkembangan karakter siswa melalui kegiatan ekstrakulikuler paduan suara di SD St. Antonius I dan II ada 3, yaitu keadaan orangtua siswa yang terbatas, penguasaan materi lagu dan kurangnya motivasi internal pada diri siswa karena keadaan terpaksa. Solusi yang dapat dicapai dari masalah tersebut adalah mengupayakan kegiatan-kegiatan penggalangan dana untuk menutupi sebagian biaya pribadi; pembiasaan disiplin dan kerja keras sejak dini untuk mempermudah siswa yang akan menjadi penerus anggota tim inti dikemudian hari; dan pengarahan minat anak dibarengi dengan ketelatenan orangtua untuk selalu mengecek perkembangan dan kondisi si anak.
\end{abstract}

Kata kunci : Perkembangan, karakter siswa, paduan suara, Beata Voce

\section{PENDAHULUAN}

\section{Latar Belakang Masalah}

Undang-Undang Nomor 20
Tahun 2003 tentang Sistem
Pendidikan Nasional pada Pasal 3
menyebutkan: "Pendidikan Nasional
berfungsi mengembangkan
kemampuan dan membentuk
karakter serta peradaban bangsa yang
bermartabat dalam rangka
mencerdaskan kehidupan bangsa,..."
(Sutarjo Adisusilo, 2014 ).
Pendidikan tidak hanya mendidik
peserta didik untuk menjadi manusia
yang cerdas, tetapi juga berkualitas.
Poses pendidikan merupakan

rangkaian usaha membimbing dan mengarahkan potensi hidup seseorang yang berupa kemampuan dasar dan kehidupan kepribadiannya sebagai makhluk hidup individu dan makhluk sosial serta dalam hubungannya dengan alam sekitarnya agar menjadi pribadi yang bertanggungjawab.

Pendidikan karakter berarti pendewasaan moral seseorang untuk semakin dapat beradaptasi dengan nilai-nilai dan norma yang berlaku di masyarakat, dimana tiap-tiap kelompok masyarakat memiliki indikator tersendiri dalam mewujudkan kehidupan masyarakat yang harmonis. Pembelajaran nilai- 
nilai karakter didapat melalui dua proses yaitu proses internal dan eksternal. Faktor internal dipengaruhi tingkat perkembangan intelektual anak sedangkan faktor eksternal dapat berupa pengaruh orangtua, kelompok sebaya dan masyarakat. Perkembangan karakter seseorang dimulai sejak anak berkembang kearah kedewasaannya.

Peran guru sangat berpengaruh terhadap proses pembelajaran dikelas. Guru sudah selayaknya menyampaikan nilai-nilai yang memberi pengaruh positif dan membangun dalam berbagai aspek proses pembelajaran. Pendidikan karakter dapat diperoleh dari sekolah dalam lingkup jam mata pelajaran maupun kegiatan ekstrakulikuler. Ekstrakurikuler adalah kegiatan yang dilakukan oleh para siswa sekolah atau universitas di luar jam belajar. Kurikulum standar kegiatan ekstrakurikuler ditujukan agar siswa dapat mengembangkan kepribadian, bakat, dan kemampuan pada bidang nonakademik. Pengembangan kegiatan ekstrakurikuler merupakan bagian dari pengembangan institusi sekolah.

Sekolah Dasar St. Antonius I dan II merupakan Sekolah Dasar Swasta Katolik yang berlokasi di Jalan Sriwijaya No. 7 Kecamatan Medan Baru Kelurahan Petisah Hulu, Medan. Sekolah Dasar Swasta Katolik St. Antonius I dan II telah mendapat akreditasi A dan menggunakan kurikulum pendidikan 2013. Sekolah ini memiliki beberapa kegiatan ekstrakulikuler yang wajib diikuti siswanya sebagai pelengkap kurikulum pendidikan. Kegiatan ekstrakulikuler berjalan secara gabungan antara Sekolah Dasar Swasta Katolik St. Antonius I dan II tanpa pemisahan. Salah satu kegiatan eksktakulikuler pilihan pada sekolah tersebut adalah kegiatan paduan suara. Paduan suara sendiri merupakan istilah yang menunjuk kepada ansambel musik yang terdiri atas penyanyi-penyanyi yang bernyanyi dalam suatu kesatuan. Lagu yang dinyanyikan dapat berbentuk satu suara atau unisono dan harmoni beberapa jenis suara. Kegiatan paduan suara tidak hanya bertujuan untuk menyanyikan sebuah komposisi musik secara matang dengan teknik bernyanyi yang baik, tetapi juga untuk menciptakan manusia yang memiliki karakter baik di dalam hidupnya.

Berdasarkan penjelasan, maka dapat dilakukan penelitian dengan judul "Perkembangan Karakter Siswa Melalui Kegiatan Ekstrakulikuler Paduan suara di SD St. Antonius I dan II Medan”.

\section{Rumusan Masalah}

Rumusan masalah dari penelitian ini adalah bagaimana perkembangan karakter siswa melalui kegiatan eksktrakulikuler paduan suara di SD Santo Antonius I dan II Medan. Untuk memperjelas permasalahan dalam penelitian, maka dapat diuraikan menjadi beberapa pertanyaan penelitian sebagai berikut

1. Bagaimana keberadaan kegiatan ekstrakulikuler paduan suara di SD St. Antonius I dan II Medan?

2. Bagaimana perkembangan karakter siswa melalui kegiatan ekstrakulikuler paduan suara di SD St. Antonius I dan II Medan?.

3. Apa kendala dan solusi dari pengembangan 
karakter siswa melalui kegiatan ekstrakulikuler paduan suara di SD St. Antonius I dan II Medan?

\section{Tujuan Penelitian}

Tujuan

merupakan

penjabaran secara deskriptif dari permasalahannya. Berhasil atau tidaknya pengembangan suatu penelitian, dapat dilihat dari tercapai tidaknya tujuan penelitian yang telah ditetapkan.

Adapun tujuan penelitian ini adalah sebagai berikut :

1. Untuk mengetahui keberadaan kegiatan ekstrakulikuler paduan suara di SD St. Antonius I dan II Medan.

2. Untuk mengetahui perkembangan karakter siswa melalui kegiatan ekstrakulikuler paduan suara di SD Swasta Katolik St. Antonius I dan II Medan.

3. Untuk mengetahui kendala dan solusi dari pengembangan karakter siswa melalui kegiatan ekstrakulikuler paduan suara di SD Swasta Katolik St. Antonius I dan II Medan.

\section{Kajian Pustaka}

\section{Perkembangan Karakter Siswa}

\section{A. Pengertian Perkembangan}

Istilah perkembangan berarti serangkaian perubahan-perubahan progressif yang terjadi sebagai akibat dari proses kematangan dan pengalaman. Warmer dalam Kemali Syarif (2015:1) menyatakan bahwa
:"Perkembangan menunjuk pada suatu proses kearah yang lebih sempurna dan tidak begitu saja dapat diulang kembali. Perkembangan menunjuk pada perubahan yang bersifat tetap dan tidak dapat diputar kembali". Menurut Syamsu Yusuf dalam Kemali Syarif (2015 :1), perkembangan dapat diartikan sebagai perubahan yang progresif dan berkesinambungan dalam diri individu dari mulai lahir sampai mati, baik menyangkut fisik/jasmaniah maupun psikis/rohaniah

\section{B. Teori Karakter}

Pembahasan karakter pada manusia tidak dapat dipisahkan dengan moral dan etika. Karakter menunjuk pada tingkah laku manusia yang dituntut untuk bertindak sesuai moral dan etika pada tatanan masyarakat. Moral adalah acuan tingkah laku. Sementara etika diartikan sebagai sistem nilai yang dianut oleh sekelompok masyarakat dan sangat mempengaruhi tingkah lakunya (Muchson dan Samsuri, 2015:3).

Untuk memenuhi ajaran moral dalam etika bermasyarakat, diperlukan pribadi dengan karakter yang terbentuk secara arif agar dapat bermasyarakat sesuai nilai sosial yang berlaku. hal ini sejalan dengan pendapat Sutarjo Adisusilo (2014 : 70) "Seseorang dikatakan berkarakter atau berwatak jika telah berhasil menyerap nilai-nilai dan keyakinan yang dikehendaki masyarakat serta digunakan sebagai kekuatan moral dalam hidupnya".

Daniel Goleman yang terkenal dengan bukunya Multiple Intelligences dan Emotional Intelligence (Sutarjo Adisusilo, 2014:79), menyebutkan bahwa 
pendidikan karakter merupakan pendidikan nilai, yang mencakup sembilan nilai dasar yang saling terkait, yaitu : Responsibility (tangung jawab), Respect (rasa hormat), Fairness (keadilan), Courage (keberanian), Honesty (kejujuran), Citizenship (rasa kebangsaan), Self-disciopline (disiplin diri), Caring (peduli), Perseverance (ketekunan)

Dalam Sutarjo Adisusilo (2015:80), jika pendidikan nilai berhasil menginternalisasikan kesembilan nilai dasar tersebut dalam diri peserta didik, maka dalam pandangan Goleman adan terbentuk seorang pribadi yang berkarakter dan pribadi yang berwatak.

Dalam pandangannya, pendidikan nilai atau karakter amat penting, sebab menurut hasil penelitiannya, keberhasilan atau sukses hidup seseorang itu $80 \%$ ditentukan oleh karakternya (kecerdasan emosional, kecerdasam sosial, dan kecerdasan spiritual) dan hanya $20 \%$ ditentukan oleh kecerdasan intelektualnya.

\section{Ekstrakulikuler Paduan Suara}

\section{A. Ekstrakulikuler}

Wiyani, dalam Noor yanti (2016:965) menyatakan bahwa :"Kegiatan ekstrakulikuler merupakan kegiatan pendidikan diluar jam pelajaran yang ditunjukkan untuk membantu perkembangan peserta didik, sesuai dengan kubutuhan, potensi, bakat, dan minat mereka melalui kegiatan yang secara khusus diselenggarakn oleh peserta didik dan atau tenaga kependidikan yang berkemampuan dan berkewenangan di sekolah"
Kegiatan ekstrakulikuler merupakan kegiatan yang dilakukan dalam mengembangkan aspek-aspek tertentu dari apa yang ditemukan pada kurikulum yang sedang dijalankan, termasuk yang berhubungan dengan bagaimana penerapan sesungguhnya dari ilmu pengetahuan yang dipelajari oleh peserta didik sesuai dengan tuntutan kebutuhan hidup mereka maupun sekitarnya.

Menurut peraturan Menteri Pendidikan dan Kebudayaan Republik Indonesia Nomor 62 Tahun 2014 tentang kegiatan ekstrakulikuler ayat dua (Noor Yanti, 2016:965), yaitu : "Kegiatan ekstrakulikuler diselenggarakan dengan tujuan untuk mengembangkan potensi, bakat, minat, kemampuan, kepribadian, kerjasama, dan kemandirian peserta didik secara optimal dalam rangka mendukung pencapaian tujuan pendidikan nasional"

$$
\text { Pengembangan potensi }
$$
peserta didik sebagaimana dimaksud dalam tujuan pendidikan nasional tersebut dapat diwujudkan pada kegiatan ekstrakulikuler yang merupakan salah satu kegiatan dalam program kulikuler yang alokasi waktunya tidak ditetapkan dalam kurikulum.

\section{B. Paduan Suara}

Menurut Hugh M. Miller, dalam Sunarto (2017:64) "Apabila dua atau lebih suaradipergunakan, medium itu disebut sebuah ansambel vokal. Ia dapat terdiri dari bagianbagian untuk dua suara (duet vokal), tiga suara (trio), empat suara (kuartet), atau lebih dari itu. Apabila sebuah ansambel terdiri dari sejumlah besar penyanyi dengan 
lebih dari satu orang menyanyikan satu suara, medium itu dikenal sebagai koor."

Kegiatan paduan suara itu ialah bernyanyi, jadi merupakan seni mengungkapkan pikiran dan perasaan melalui nada dan kata-kata, dengan demikian semua syarat-syarat untuk bernyanyi dengan baik harus dikuasai pula oleh semua anggota paduan suara. Bahkan selain menguasai semua syarat-syarat itu, harus pula menyeragamkannya, seperti dalam produksi nada, mutu suara, ucapan, intonasi, pernapasan, sikap, ekspresi, dan sebagainya, sehingga menghasilkan ungkapan yang padu, seolah-olah semuanya keluar dari seseorang yang bermulut banyak. (Jamalus, 1981:95).

Kelompok paduan suara yang menjadi objek dalam penelitian ini merupakan kelompok paduan suara sekolah dengan anggota anak-anak perempuan dan laki-laki rentang usia 9-14 tahun. Adapun pembagian kelompok suara, dikategorikan menjadi kelompok suara soprano dan alto. Pada paduan suara sekolah, yang menjadi anggota paduan suara tentulah peserta didik. Untuk mempersiapkan siswa dalam penampilan, harus ditentukan anakanak yang akan ikut dalam pertunjukan tersebut. Pengalaman naik panggung ini besar artinya bagi anak-anak. Mereka akan bangga dengan pengalaman barunya, dan dapat pula mempengaruhi perkembangan pribadi anak itu selanjutnya (Jamalus, 1981:96).

\section{Metode Penelitian}

Metode yang digunakan dalam penelitian adalah metode deskriptif kualitatif. Yaitu metode yang memberikan gambaran tentang suatu keadaan berdasarkan faktafakta yang ditemukan dan yang ada dilapangan. Penelitian ini melibatkan kelompok sampel yang terdiri dari dua anak per kelompok suara, yang berasa dari tital populasi keseluruhan anggota paduan suara berjumlah 31 orang.

Pengumpulan data dalam penelitian kualitatif dapat dilakukan dengan menggunakan teknik kondisi yang alami, sunber data primer, dan lebih banyak teknik observasi berperan serta, wawancara mendalam, dan dokumentasi. Data yang diperolah adalah hasil wawancara dan observasi dengan sampel penelitian berdasarkan indikator perkembangan karakter yang telah disusun sebelumnya oleh peneliti dan pelatih paduan suara. Hasil penelitian kemudian disusun untuk memperoleh pembuktian perkembangan karakter siswa melalui kegiatan ekstrakulikuler paduan suara di SD Santo Antonius I dan II Medan.

\section{Hasil Penelitian dan Pembahasan}

Kegiatan ekstrakulikuler paduan suara di SD Swasta Katolik Santo Antonius I dan II Medan merupakan ekstrakulikuler pilihan, yang diresmikan sejak Oktober 2010. Kegiatan ini memiliki produk bernama paduan suara Beata Voce. Anggota paduan suara Beata Voce merupakan siswa yang diseleksi secara langsung oleh pelatih dari anggota ekstrakulikuler paduan suara gabungan Antonius I dan Antonius II. Paduan suara ini dilatih oleh Hendra F. Lingga.

Pada ekstrakulikuler paduan suara terdadapat beberapa nilai karakter yang sesuai dengan kegiatan berproses dalam ekstrakulikuler. 
Pembentukan karakter melalui kegiatan ekstrakulikuler paduan suara di SD Swasta Katolik St. Antonius I dan II Medan dilakukan melalui peran tim pelatih paduan suara sebagai pembimbing. Mereka berperan memberi dukungan dan memfasilitasi siswa. Nilai tersebut ditemukan melalui wawancara dengan pelatih paduan suara, guru pembimbing ekstrakulikuler.

Terdapat tujuh nilai karakter yang muncul dalam kegiatan ekstrakulikuler paduan suara di SD Swasta Katolik Santo Antonius I dan II Medan. Antara lain : Tanggung Jawab, Disiplin, Teguh Pendirian, Komitmen, Religius, Kerja Keras, dan Bersahabat/ Komunikatif. Berdasarkan penelitian atas empat kelompok suara, yaitu Sopran 1, Sopran 2, Alto 1, dan Alto 2, didapatkan hasil :

1. Perkembangan karakter kelompok suara Sopran 1 berada dalam kondisi sangat baik, dan karakter yang perlu lebih dikembangkan adalah kerja keras dan bersahabat/komunikatif.

2. Perkembangan karakter kelompok suara Sopran 2 berada dalam kondisi sangat baik, dan karakter yang perlu lebih dikembangkan adalah kerja keras dan teguh pendirian.

3. Perkembangan karakter kelompok suara Alto 1 berada dalam kondisi baik, dan karakter yang perlu lebih dikembangkan adalah tanggung jawab, disiplin, kerja keras, teguh pendirian, dan bersahabat/komunikatif.
4. Perkembangan karakter kelompok suara Alto 2 berada dalam kondisi baik, dan karakter yang perlu lebih dikembangkan adalah disiplin, kerja keras, teguh pendirian, dan komitmen.

5. Karakter yang perkembangannya kurang maksimal dari ketujuh nilai karakter yang ditemukan adalah kerja keras.

Kendala dari perkembangan karakter siswa melalui kegiatan ekstrakulikuler paduan suara di SD St. Antonius I dan II ada 3, yaitu keadaan orangtua siswa yang terbatas, dimana sangat mempengaruhi pergerakan kegiatan anaknya; penguasaan materi lagu anggota Beata Voce yang sulit mencapai keinginan pelatih pada tahap pemolesan; dam kurangnya motivasi internal pada diri siswa karena keadaan terpaksa. Solusi yang dapat dicapai dari masalah tersebut adalah mengupayakan kegiatankegiatan penggalangan dana untuk menutupi sebagian biaya pribadi; pembiasaan disiplin dan kerja keras sejak dini untuk mempermudah siswa yang akan menjadi penerus anggota tim inti dikemudian hari; dam pengagarahan minat anak dibarengi dengan ketelatenan orangtua untuk selalu mengecek perkembangan dan kondisi si anak. Pihak sekolah juga bisa memonitor prestasi akademik siswa yang bersangkutan untuk menghindari perasaan terbebani akan suatu kegiatan sekolah.

\section{Simpulan}


Berdasarkan penelitian, dapat dinyatakan bahwa siswa dalam kelompok suara Sopran 1 berada dalam kondisi sangat baik, siswa dalam kelompok suara Sopran 2 berada dalam kondisi sangat baik, siswa dalam kelompok suara Alto 1 berada dalam kondisi baik, dan siswa dalam kelompok suara Alto 2 berada dalam kondisi baik, dan karakter yang kurang maksimal pengembangannya dalah kerja keras. Kendala dari perkembangan karakter siswa melalui kegiatan ekstrakulikuler paduan suara di SD St. Antonius I dan II ada 3, yaitu keadaan orangtua siswa yang terbatas, penguasaan materi lagu dan kurangnya motivasi internal pada diri siswa karena keadaan terpaksa. Solusi yang dapat dicapai dari masalah tersebut adalah mengupayakan kegiatan-kegiatan penggalangan dana untuk menutupi sebagian biaya pribadi; pembiasaan disiplin dan kerja keras sejak dini untuk mempermudah siswa yang akan menjadi penerus anggota tim inti dikemudian hari; dan pengarahan minat anak dibarengi dengan ketelatenan orangtua untuk selalu mengecek perkembangan dan kondisi si anak.

\section{Daftar Pustaka}

Adisusilo, $\quad$ Sutarjo. 2014. Pembelajaran Nilai-nilai Karakter. Jakarta : Rajawali Press

Jamalus. 1981. Musik 4. Jakarta: CV Titik Terang

Muchson, Samsuri. 2013. Dasardasar Pendidikan Moral. Yogyakarta: Penerbit Ombak

Sunarto, Hugh M.Miller. (ED). 2017. Apresiasi Musik. Yogyakarta : Thafamedia

Syarif, Kemali. 2015. Perkembangan Peserta Didik. Medan : Unimed Press

Yanti, Noor. 2016. Pelaksanaan Kegiatan Ekstrakurikuler dalam rangka Pengembangan Nilai-nilai Karakter Siswa untuk Menjadi Warga Negara yang Baik di SMA Korpri Banjarmasin. Jurnal, Universitas Lambung Mangkurat. 